\title{
PENGARUH MODEL PEMBELAJARAN LEARNING CYCLE TERHADAP KEMAMPUAN PEMAHAMAN DAN KONEKSI MATEMATIS SISWA SMP
}

\author{
Yenni $^{1}$, Risna Komalasari ${ }^{2}$ \\ ${ }^{1}$ Universitas Muhammadiyah Tangerang \\ yenni_aan@yahoo.co.id \\ ${ }^{2}$ Universitas Muhammadiyah Tangerang \\ risna_komalasari@ymail.com
}

\begin{abstract}
ABSTRAK
Penelitian ini dilatarbelakangi kemampuan pemahaman dan koneksi matematis siswa tingkat SMP yang rendah. Tujuan penelitian untuk mengetahui pengaruh model pembelajaran Learning Cycle terhadap kemampuan pemahaman dan koneksi matematiks siswa. Populasi diambil dari siswa SMP Negeri 2 Cikupa Kabupaten Tangerang berjumlah 408 siswa. Teknik pengambilan sampel menggunakan Purposive Sampling, terpilih kelas VII C sebagai kelas kontrol berjumlah 44 siswa dan VII D sebagai kelas eksperimen berjumlah 47 siswa. Kelas kontrol diberikan model pembelajaran konvensional dan kelas eksperimen diberikan model pembelajaran Learning Cycle. Metode penelitian yang digunakan adalah Quasi Eksperimen dengan Nonequivalent control grup design. Instrument tes berbentuk uraian sebanyak 4 soal pemahaman matematika dan 5 soal koneksi matematika. Uji persyaratan analisis menggunakah Chi Kuadrat dan uji Fisher. Hasil data pretes menunjukkan kelas kontrol dan eksperimen memiliki data yang berdistribusi normal, homogen dan tidak terdapat perbedaan baik kemampuan pemahaman maupun kemampuan koneksi matematika. Hasil data postes kemampuan pemahaman matematika berdistribusi normal, homogen, dan terdapat perbedaan kemampuan pemahaman dan koneksi matematika antara kelas kontrol dan eksperimen. Hasil data postes kemampuan koneksi matematika berdistribusi tidak normal dan terdapat perbedaan kemampuan koneksi matematika antara kelas kontrol dan eksperimen. Dapat disimpulkan bahwa penggunaan model pembelajaran Learning Cycle berpengaruh terhadap kemampuan pemahaman dan koneksi matematis siswa.
\end{abstract}

Kata Kunci : Learning Cycle, pemahaman matematis, koneksi matematis

\section{PENDAHULUAN}

Kemampuan pemahaman dan koneksi matematis siswa tingkat SMP masih rendah. Pendapat tersebut diawali dengan temuan posisi Indonesia oleh survey PISA. PISA (Program for International Student Assessment) di bawah organisasi OECD (Organization Economic Cooperation and Development) rutin mengadakan survei tentang kemampuan siswa dan sistem pendidikan setiap 3 tahun sekali. Terakhir PISA melakukan penelitian pada tahun 2012 dan dirilis pada Desember 2013, berdasarkan survei yang melibatkan 65 negara dengan responen sebanyak 510 ribu pelajar berusia 15-16 tahun dan ada 3 kemampuan siswa yang dinilai yaitu salah satunya adalah kemampuan matematika yang 
menempati peringkat 64 dari 65 negara yang diteliti. Hal ini menunjukkan bahwa kemampuan matematis di Indonesia sangatlah rendah.

Berdasarkan wawancara peneliti dengan guru mata pelajaran matematika kelas VII di SMP Negeri 2 Cikupa, kriteria ketuntasan minimal (KKM) pada mata pelajaran matematika adalah 7,00. Berdasarkan hasil ujian akhir semester (UAS) satu tahun ajaran 2014/2015 hanya 38,82 \% siswa yang mampu mendapatkan nilai di atas KKM. Artinya 61,18\% siswa mendapatkan nilai di bawah KKM. Proses kegiatan belajar mengajar kelas VII di SMPN 2 Cikupa sudah dilakukan secara optimal akan tetapi siswa masih kesulitan dalam memahami konsep matematika, menyatakan ulang sebuah konsep dan menghubungkan soal-soal kehidupan sehari-hari kedalam model matematika dan menentukan rumus apa yang akan dipakai jika dihadapkan pada soal kehidupan sehari-hari. Berdasarkan wawancara peneliti terhadap siswa kelas VII yang menjadi kesulitan dalam belajar matematika adalah ketika siswa dihadapkan pada soal cerita atau yang menyangkut ke dalam masalah kehidupan sehari-hari.

Pemerintah telah menegaskan, bahwa setelah mempelari matematika siswa harus memiliki kemampuan: 1) Memahami konsep matematika, menjelaskan keterkaitan antar konsep dan mengaplikasikan konsep algoritma secara luwes, akurat, efisien dan tepat dalam pemecahan masalah, 2) Menggunakan penalaran pada pola dan sifat, melakukan manipulasi matematika dalam membuat generalisasi, menyusun bukti, atau menjelaskan gagasan dalam pernyataan matematika, 3) Memecahkan masalah yang meliputi kemampuan memahami masalah, merancang model matematika, menyelesaikan model, dan menafsirkan solusi yang diperoleh, 4) Mengkomunikasikan gagasan dengan simbol, tabel, diagram, atau media lain untuk memperjelas keadaan atau masalah. 5) Memiliki sikap menghargai kegunaan matematika dalam kehidupan, yaitu memiliki rasa ingin tahu, perhatian, dan minat dalam mempelajari matematika, serta sikap ulet dan percaya diri dalam pemecahan masalah. (Wardani, 2008). Tertulis jelas pada tujuan yang tercantum dalam DEPDIKNAS tersebut, kemampuan pemahaman dan koneksi matematika wajib dimiliki oleh siswa.

Permasalahan pada kemampuan pemahaman metematis banyak ditemukan sekolah menengah pertama. Hasil penelitian yang dilakukan di MTs Manbaul Ulum Kota Tangerang, siswa kesulitan dalam mengungkapkan cara lain untuk menjawab soal. Siswa cenderung hafalan untuk menyelesaikan soal. Proses bagaimana menemukan rumus luas, 
keliling, sebatas pengetahuan turunan. Jadi, pengetahuan merupakan bentuk transfer tanpa memahami bentuk dari objeknya (Yenni, 2012). Temuan serupa terjadi di SMPN 4 Kota Tangerang diperoleh data sebagai berikut : 1) Guru mendominasi kegiatan Belajar Mengajar (KBM), 2) Siswa kurang mendapat kesempatan untuk mengungkapkan ide, 3) Cara siswa menyelesaikan masalah cendurung sama dengan contoh soal. 4) Siswa aktif karena diminta guru. Kalaupun siswa maju untuk menyekesaikan soal,. biasanya disuruh oleh guru atau siswa itu-itu saja. Bukti serupa ditemukan di SMP PGRI jatiuwung Kabupaten Tangerang. Diperoleh temuan bahwa kemampuan siswa dalam menyatakan ulang sebuah konsep yang telah dipelajari hanya mencapai 45\%. (Widaningsih, Yenni, 2015). Permasalahan koneksi matematis tidak kalah penting. Sumarmo (2010) mengungkapkan, dalam berpikir dan belajar matematika siswa dituntut untuk memahami koneksi antara ide-ide matematik, antara matematika dengan bidang studi lainnya. Pengertian ini tidak bisa terpisah-pisah, harus saling berkaitan.

Banyak faktor yang mempengaruhi kemampuan matematis siswa. Berdasarkan temuan di SMPN 2 Cikupa, salah satu penyebabnya adalah karena siswa kurang diberi kesempatan untuk mengungkapkan ide dan gagasan matematika. Hal tersbut terjadi karena guru masih belum melakukan variasi mengajar. Padahal, salah satu ketrampilan dasar yang wajib dikuasai oleh guru adalah kemampuan memvariasikan pembelajaran. Selama ini, pembelajaran matematika masih berpusat kepada guru. Pembelajaran dengan pendekatan teacher centered ini banyak digunakan karena guru dapat dengan mudah mengatur waktu, singga dapat disesuaikan dengan materi yang sulit sekalipun. Yang terlupakan adalah, bahwa siswa kurang diberi kesempatan untuk mengungkapkan pendapat, dan cenderung menerima transfer knowledge dibanding memahami.

Dimyati dan Mudjiono (2012) berpendapat, proses belajar ditentukan oleh tiga tahapan penting, yaitu kegiatan sebelum belajar, selama proses belajar, dan sesudah belajar. Proses kegiatan sebelum mengajar seharusnya dapat mengarahkan siswa kepada keinginginan belajar matematika. Kesulitan yang dialami siswa biasanya ada dalam proses kegiatan belajar, guru sebagai fasilitator belajar berperan penting. Pemilihan pendekatan, metode dan stategi pembelajaran yang tepat dapat membantu kesulitan belajar siswa khususnya dalam menguasai kemampuan pemahaman dan koneksi matematika siswa. Sehingga pada proses setelah belajar siswa diharapkan untuk mendapatkan prestasi belajar yaitu berupa pemahaman dan koneksi matematika siswa. Perlu penanganan segera, agar 
kemampuan pemahaman dan koneksi siswa SMP dapat berkembang sesuai harapan. Salah satu cara yang dapat dilakukan adalah dengan merubah model pembelajaran yang biasa digunakan dengan model pembelajaran yang menuntut siswa dapat lebih aktiv dan memperoleh kesempatan untuk mengeksplor kemampuannya. Penelitian ini dilakukan dengan rumusan masalah, apakah terdapat perbedaan kemampuan pemahaman dan koneksi matematis siwa antara yang mendapat medel pembelajaran learning cycle dan siswa yang mendapat model pembelajaran konvensional.

\section{Pemahaman Matematis}

Pemahaman matematis mengerucut pada kemampuan setingkat lebih tinggi dari pengetahuan yang hasilnya siswa dapat menafsirkan, memaparkan dan menyimpulkan suatu pengetahuan menurut diri sendiri dan mengeksplorasi pengetahuan tersebut tanpa mengurangi arti dari suatu pengetahuan tersebut (Sagala, 2013; Soemarmo, 2013). Indikator dari pemahaman matematis yaitu sebagai berikut : 1) Menyatakan ulang sebuah konsep, 2) Mengidentifikasi hal-hal yang relevan dengan suatu konsep dengan cara yang tepat, 3) Kemampuan menerapkan konsep secara algoritma, dan 4) Memberi contoh dan bukan contoh dari suatu konsep.

\section{Koneksi Matematis}

Koneksi matematis adalah bahwa koneksi matematik merupakan kemampuan yang dapat menghubungkan konsep matematika kedalam konteks lain (Andoko, Turmudi dan Tatang, 2014). Indikator koneksi matematis yang akan digunakan dalam penelitian ini yaitu: 1) Mencari hubungan berbagai representasi konsep dan prosedur, 2) Memahami hubungan antar topik, 3) Menerapkan matematika dalam kehidupan sehari-hari dan 4) Memahami representasi aquivalen konsep yang sama.

\section{Learning Cycle}

Model pembelajaran learning cycle adalah merupakan pembelajaran koperatif bersiklus yang memiliki 5 fase atau biasa disebut 5E yaitu meliputi Engagement (Undangan), Eksploration (Eksplorasi), Eksplanation (Penjelasan), Elaboration (Pengembangan), dan Evaluation (Evaluasi). Kemampuan koneksi matematis siswa akan dimunculkan pada fase Engangement dimana siswa akan mengkoneksikan konsep pelajaran kedalam kehidupan sehari-hari dan pemahaman matematis siswa akan muncul 
pada fase Eksplanation dimana siswa akan menjabarkan konsep pelajaran menurut pemahamannya sendiri. Learning Cycle memberikan kesempatan kepada siswa untuk berperan aktif di dalam kelas dan menuntut siswa untuk mempelajari materi secara individu kemudian disajikan ke dalam kelompok (Ngalimun, 2014, h.145). Dalam model ini guru hanya menjadi fasilitator, kegiatan belajar sepenuhnya dilakukan oleh siswa. Teori tersebut di dukung oleh David Kolb, ia menyebutkan bahwa Learning Cycle merupakan model pembelajaran bersiklus (Huda, 2014).

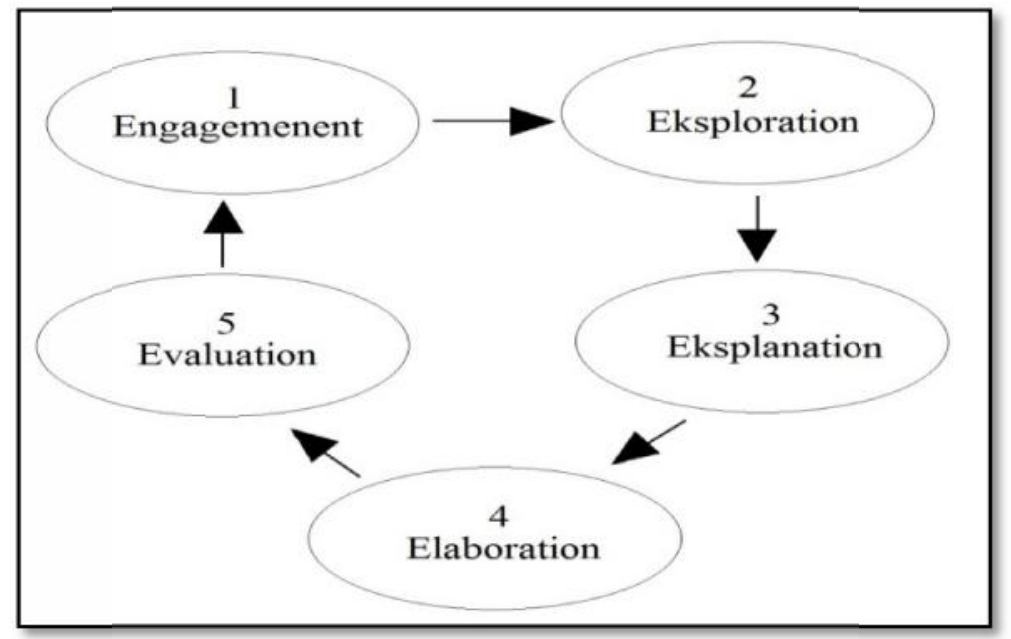

Gambar 1. Siklus Learning Cycle

1) Engangement (Undangan)

Mempersiapkan siswa agar terkondisikan, menggali pengetahuan awal dan keingintahuan siswa dengan topik yang akan diajarkan dibangkitkan.

2) Eksploration (Eksplorasi)

Siswa secara berkelompok bekerjasama melakukan pengamatan tanpa pengajaran langsung dari guru.

3) Ekplanation (Penjelasan)

Guru mendorong siswa untuk menjelaskan konsep dengan kalimat mereka sendiri.

4) Elaboration (Pengembangan)

Siswa mengembangkan konsep dan keterampilan dalam situasi baru melalui kegiatankegiatan seperti praktikum lanjutan.

5) Evaluation (Evaluasi)

Guru menilai apakah pembelajaran sudah berlangsung baik dengan jalan memberikan tes kepada siswa. 


\section{METODE PENELITIAN}

Metode yang digunakan adalah Quasi Experimental Design. Metode ini dipilih karena pemilihan sampel tidak mungkin diacak secara random. Pertimbangannya, jika pelaksanaan penelitian dijadwalkan, dikhawatirkan akan menggagu jadwal utama dikelas asal.

\section{Populasi dan Sampel}

Populasi dalam penelitian ini adalah seluruh siswa kelas VII SMP Negeri 2 Cikupa yang berjumlah 408 siswa. Proses pengambilan sampel menggunakan nonprobalility sampling dengan teknik purposive sampling. Kelas terpilih karena pertimbangan guru. Beberapa pertimbangan yang digunakan adalah bahwa kemampuan matematika siswa secara keseluhan relative sama, dan kedua kelas bermasalah pada kemampuan pemahaman dan koneksi matematisnya. Desain penelitian Non Equivalent Control Group Design. Rancangan penelitiannya sebagai berikut :

Tabel 1. Desain penelitian

\begin{tabular}{cccc}
\hline $\mathrm{E}$ & $0_{1}$ & $\times$ & $0_{2}$ \\
\cline { 2 - 4 } $\mathrm{K}$ & $0_{3}$ & $\times$ & $0_{4}$
\end{tabular}

(Arikunto, 2010)

Kelas eksperimen E diberikan metode learning cycle, sedangkan kelas control $\mathrm{K}$ diberikan metode konvensional. $0_{1}$ data pretes kelas eksperimen. $0_{2}$ merupakan data postes kelas eksperimen. $0_{3}$ menyimbolkan data pretes kelas control dan $0_{4}$ simbol dari data postes kelas control.

Teknik pengumpulan data menggunakan teknik tes. Tes berbentuk uraian dengan indicator kemampuan pemahaman dan koneksi matematis.

Tabel 2. Kisi-kisi instrument pretes dan postes

\begin{tabular}{|c|c|c|c|c|c|}
\hline $\begin{array}{l}\text { Standar } \\
\text { Kompeten } \\
\text { si }\end{array}$ & $\begin{array}{l}\text { Kemampuan } \\
\text { matematis }\end{array}$ & Aspek yang diukur & Indikator & $\begin{array}{l}\text { No } \\
\text { soal }\end{array}$ & $\begin{array}{l}\text { Skor } \\
\text { mak } \\
\text { s }\end{array}$ \\
\hline $\begin{array}{l}\text { Memaham } \\
\text { i konsep } \\
\text { segiempat }\end{array}$ & $\begin{array}{l}\text { Kemampuan } \\
\text { Pemahaman }\end{array}$ & $\begin{array}{l}\text { Menyatakan ulang sebuah } \\
\text { konsep }\end{array}$ & $\begin{array}{l}\text { Siswa dapat menyelesaikan konsep } \\
\text { matematika dari gambar segitiga } \\
\text { sama sisi }\end{array}$ & 1 & 7 \\
\hline $\begin{array}{l}\text { dan } \\
\text { segitiga } \\
\text { serta }\end{array}$ & Matematis & $\begin{array}{l}\text { Mengidentifikasi hal-hal } \\
\text { yang relevan dengan suatu } \\
\text { konsep dengan cara yang }\end{array}$ & $\begin{array}{l}\text { Siswa dapat menyelesaikan soal } \\
\text { permasalahan matematika yang } \\
\text { berhubungan dengan trapesium }\end{array}$ & 6 & 4 \\
\hline
\end{tabular}




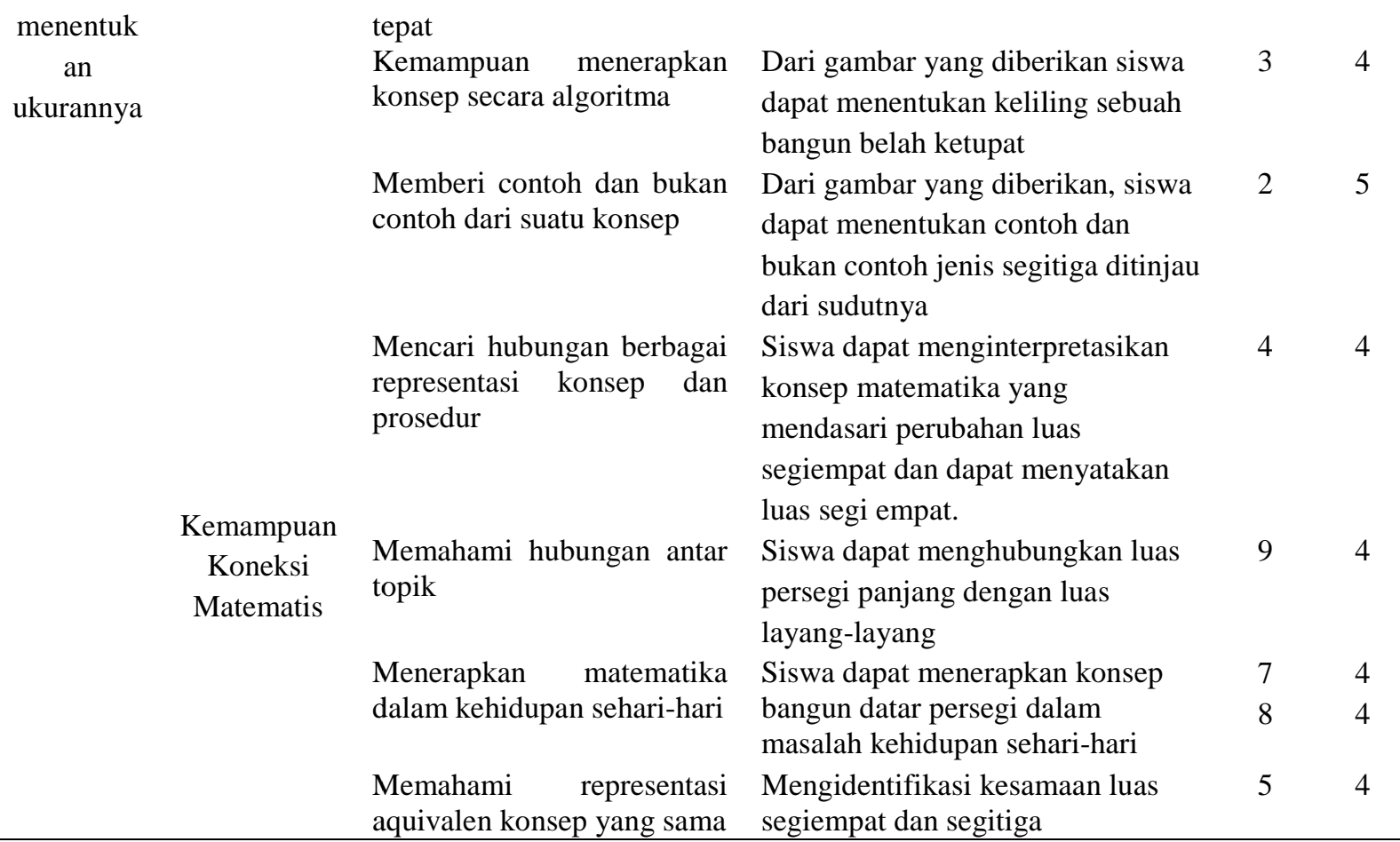

Sebelum digunakan sebagai instrumen pretes dan postes, terlebih dahulu soal diujicobakan, sehingga soal layak dijadikan sebagai instrument utama. Uji coba soal meliputi validitas, reliabelitas, daya beda dan tingkat kesukaran.

Tabel 3. Hasil Uji coba Soal

\begin{tabular}{ccccccccccc}
\hline \multirow{2}{*}{$\begin{array}{c}\text { No } \\
\text { Soal }\end{array}$} & \multicolumn{4}{c}{ Validitas $^{1)}$} & & \multicolumn{2}{c}{ Reliabelitas $^{2)}$} & \multicolumn{2}{c}{ Daya Pembeda ${ }^{3)}$} & \multicolumn{2}{c}{ Tingkat Kesukaran $^{4)}$} \\
\cline { 2 - 11 } & $\mathrm{r}_{\mathrm{xy}}$ & $\mathrm{t}_{\text {hitung }}$ & $\mathrm{t}_{\text {tabel }}$ & Ket & $\mathrm{r}_{11}$ & Ket & DP & Ket & TK & Ket \\
\hline 1 & 0,588 & 4,482 & 2,025 & Valid & 0795 & Reliabel & 0,523 & Baik & 0,602 & Sedang \\
2 & 0,446 & 3,072 & 2,025 & Valid & & tinggi & 0,318 & Cukup & 0,364 & Sedang \\
3 & 0,474 & 2,899 & 2,025 & Valid & & & 0,455 & Baik & 0,273 & Sedang \\
4 & 0,724 & 6,469 & 2,025 & Valid & & 0,568 & Baik & 0,489 & Sedang \\
5 & 0,676 & 5,655 & 2,025 & Valid & & 0,727 & Sangat & 0,568 & Sedang \\
6 & 0,392 & 2,627 & 2,025 & Valid & & 0,295 & Cukup & 0,193 & Sukar \\
7 & 0,743 & 6,852 & 2,025 & Valid & & & 0,659 & Baik & 0,33 & Sedang \\
8 & 0,693 & 5,599 & 2,025 & Valid & & & 0,682 & Baik & 0,341 & Sedang \\
9 & 0,714 & 6,287 & 2,025 & Valid & & 0,523 & Baik & 0,261 & Sukar \\
\hline
\end{tabular}

1) Product Moment,

2) Alfa Cronbach,

3) $\mathrm{DP}=\frac{\mathrm{S}-\mathrm{S}}{\mathrm{L}}$,

4) $\mathrm{TK}=\frac{S+S}{L+L}$ 


\section{HASIL DAN PEMBAHASAN}

Berdasarkan deskripsi data pretes diperoleh data awal kemampuan pemahaman dan koneksi siswa sebagai berikut:

\section{Analisis Kemampuan Awal Pemahaman dan Koneksi Matematis}

Tabel 4. Deskripsi kemampuan awal.

\begin{tabular}{clccccccc}
\hline $\begin{array}{c}\text { Sampel } \\
\text { (Kelas) }\end{array}$ & Kemampuan & $\begin{array}{c}\text { Nilai } \\
\text { Min }\end{array}$ & $\begin{array}{c}\text { Nilai } \\
\text { Max }\end{array}$ & $\begin{array}{c}\text { Modu } \\
\mathrm{s}\end{array}$ & Median & $\begin{array}{c}\text { Rata- } \\
\text { rata }\end{array}$ & $\begin{array}{c}\text { Standar } \\
\text { Deviasi } \\
(\mathrm{s})\end{array}$ & $\begin{array}{c}\text { Varians } \\
\left(\mathrm{s}^{2}\right)\end{array}$ \\
\hline Kontrol & Pemahaman & 0 & 69 & 34,1 & 27,5 & 27,45 & 18,04 & 325,61 \\
& Koneksi & 0 & 75 & 34,7 & 30,96 & 32,25 & 20,91 & 286,5 \\
Eksperime & Pemahaman & 0 & 69 & 33,8 & 28,8 & 28,54 & 17,1 & 292,3 \\
$\mathrm{n}$ & Koneksi & 0 & 65 & 26,2 & 31,6 & 33,01 & 19,67 & 387,18 \\
\hline
\end{tabular}

Dari tabel 4 terlihat, bahwa nilai awal kedua kelas tidak terlalu berbeda. Namun demikian, keadaan ini belum cukup untuk menyimpulkan, apakah kondisi kedua kelas memang sama atau berbeda kemampuan awalnyanya. Selanjutnya dilakukan analisis data pretes sebagai berikut:

Tabel 5. Uji persyaratan data pretes

\begin{tabular}{|c|c|c|c|c|}
\hline \multirow[b]{2}{*}{ Jenis Uji } & \multicolumn{2}{|c|}{ Pemahaman Matematis } & \multicolumn{2}{|c|}{ Konesi Matematis } \\
\hline & Kelas Kontrol & $\begin{array}{c}\text { Kelas } \\
\text { Eksperimen }\end{array}$ & Kelas Kontrol & $\begin{array}{c}\text { Kelas } \\
\text { Eksperimen }\end{array}$ \\
\hline Normalitas ${ }^{1)}$ & $\begin{array}{c}\chi_{\text {hitung }}^{2}=11,27 \\
\chi_{\text {tabel }}^{2}=12,59 \\
\text { normal }\end{array}$ & $\begin{array}{c}\chi^{2} \text { hitung }=6,97 \\
\chi_{\text {tabel }}^{2}=12,59 \\
\text { normal }\end{array}$ & $\begin{array}{c}\chi_{\text {hitung }}^{2}=13,33 \\
\chi_{\text {tabel }}^{2}=12,59 \\
\text { normal }\end{array}$ & $\begin{array}{c}\chi_{\text {hitung }}^{2}=12,02 \\
\chi_{\text {tabel }}^{2}=12,592 \\
\text { normal }\end{array}$ \\
\hline Homogenitas $^{2)}$ & $\begin{array}{r}\mathrm{F}_{\text {hitur }} \\
\mathrm{F}_{\text {tabe }} \\
\mathrm{Ho}\end{array}$ & $\begin{array}{c}=1,11 \\
1,64 \\
\text { gen }\end{array}$ & $\begin{array}{l}\mathrm{F}_{\text {hitun }} \\
\mathrm{F}_{\text {tabl }} \\
\text { Hol }\end{array}$ & $\begin{array}{l}=1,13 \\
=1,64 \\
\text { ogen }\end{array}$ \\
\hline
\end{tabular}
1) Uji Chi Kuadrat,
2) Uji Fisher

Berdasarkan tabel 5 diperoleh data, bahwa kelas eksperimen dan kelas control pada kemampuan awal berdistribusi normal dan homogen. Selanjutnya, dilakukan uji perbedaan rata-rata untuk melihat terdapat atau tidak terdapat perbedaan kemampuan awal pemahaman dan koneksi matematis siswa. 
Tabel 6. Uji Beda rata-rata kemampuan awal

\begin{tabular}{lcccccccc}
\hline \multicolumn{1}{c}{ Kemampuan } & \multicolumn{3}{c}{ Kelas Kontrol } & \multicolumn{3}{c}{ Kelas Eksperimen } & \multirow{2}{*}{$\mathrm{t}_{\text {hitung }}$} & $\mathrm{t}_{\text {tabel }}$ \\
\hline Pemahaman & $\bar{X}$ & $\mathrm{~S}$ & $\mathrm{~S}^{2}$ & $\bar{X}$ & $\mathrm{~S}$ & $\mathrm{~S}^{2}$ & \\
Koneksi & 27,45 & 18,04 & 325,61 & 28,54 & 17,1 & 292,3 & $-0,29$ & 2,009 \\
$\mathrm{H}_{0}=$ tidak terdapat perbedaan kemampuan pemanam dan koneksi matematis siswa anatar kelas eksperimen \\
$\quad 32,25$ & 20,91 & 437,19 & 33,01 & 19,67 & 387,18 & $-0,18$ & 2,009 \\
$\quad$ dan kelas kontrol.
\end{tabular}

Dari tabel terlihat, nilai $-\mathrm{t}_{\text {tabel }} \leq \mathrm{t}_{\text {hitung }} \leq \mathrm{t}_{\text {tabel }}$. ini berarti bahwa $\mathrm{H}_{0}$ diterima atau dapat dikatakan tidak terdapat perbedaan rata-rata kemampuan pemahaman dan koneksi matematis siswa antara kelas eksperimen dan kelas control.

\section{Analisis Kemampuan Akhir Pemahaman dan Koneksi Matematis}

Tabel 7. Deskripsi kemampuan akhir.

\begin{tabular}{clccccccc}
\hline $\begin{array}{c}\text { Sampel } \\
\text { (Kelas) }\end{array}$ & Kemampuan & $\begin{array}{c}\text { Nilai } \\
\text { Min }\end{array}$ & $\begin{array}{c}\text { Nilai } \\
\text { Max }\end{array}$ & $\begin{array}{c}\text { Modu } \\
\mathrm{s}\end{array}$ & Median & $\begin{array}{c}\text { Rata- } \\
\text { rata }\end{array}$ & $\begin{array}{c}\text { Standar } \\
\text { Deviasi } \\
(\mathrm{s})\end{array}$ & $\begin{array}{c}\text { Varians } \\
\left(\mathrm{s}^{2}\right)\end{array}$ \\
\hline Kontrol & Pemahaman & 6 & 100 & 40,08 & 47,5 & 51,31 & 23,49 & 551,98 \\
& Koneksi & 5 & 100 & 82,9 & 58,82 & 58,91 & 26,56 & 705,63 \\
Eksperime & Pemahaman & 13 & 94 & 74,54 & 64,7 & 61,14 & 20,68 & 427,76 \\
n & Koneksi & 0 & 100 & 80,5 & 70,3 & 60,94 & 28,79 & 829,26 \\
\hline
\end{tabular}

Pada tes akhir, terlihat ada siswa yang memperoleh nilai sempurna, yaitu 100 baik di kelas eksperimen maupun control. Artinya ada siswa yang melampaui nilai KKM yang ditetapkan sekolah, yaitu 70 .

Pada tes akhir, terlihat ada siswa yang memperoleh nilai sempurna, yaitu 100 baik di kelas eksperimen maupun control. Artinya ada siswa yang melampaui nilai KKM yang ditetapkan sekolah, yaitu 70 .

Tabel 8. Uji persyaratan data postes

\begin{tabular}{|c|c|c|c|c|}
\hline \multirow[b]{2}{*}{ Jenis Uji } & \multicolumn{2}{|c|}{ Pemahaman Matematis } & \multicolumn{2}{|c|}{ Konesi Matematis } \\
\hline & Kelas Kontrol & $\begin{array}{c}\text { Kelas } \\
\text { Eksperimen }\end{array}$ & Kelas Kontrol & $\begin{array}{c}\text { Kelas } \\
\text { Eksperimen }\end{array}$ \\
\hline Normalitas $^{1)}$ & $\begin{array}{c}\chi_{\text {hitung }}^{2}=7,65 \\
\chi_{\text {tabel }}^{2}=12,59 \\
\text { Normal }\end{array}$ & $\begin{array}{c}\chi_{\text {hitung }}^{2}=10,03 \\
\chi_{\text {tabel }}^{2}=12,59 \\
\text { normal }\end{array}$ & $\begin{array}{c}\chi_{\text {hitung }}^{2}=13,33 \\
\chi_{\text {tabel }}=12,59 \\
\text { Tidak normal }\end{array}$ & $\begin{array}{c}\chi_{\text {hitung }}^{2}=20,07 \\
\chi_{\text {tabel }}^{2}=12,592 \\
\text { Tidak normal }\end{array}$ \\
\hline Homogenitas ${ }^{2)}$ & $\begin{array}{r}\mathrm{F}_{\text {hitun }} \\
\mathrm{F}_{\text {tabe }} \\
\text { Ho }\end{array}$ & $\begin{array}{l}=1,29 \\
=1,64 \\
\text { ogen }\end{array}$ & & \\
\hline
\end{tabular}

1) Uji Chi Kuadrat,

2) Uji Fisher 
Terlihat, bahwa di kemampuan akhir, kemampuan koneksi matematis siswa di kedua kelas tidak berdistribusi normal. dengan demikian, uji keefektifan metode dilakukan dengan statistic non parametric.

Tabel 9. Uji Beda rata-rata kemampuan akhir pemahaman matematis

\begin{tabular}{lcccccccc}
\hline \multirow{2}{*}{ Kemampuan } & \multicolumn{3}{c}{ Kelas Kontrol } & \multicolumn{3}{c}{ Kelas Eksperimen } & \multirow{2}{*}{$\mathrm{t}_{\text {hitung }}$} & $\mathrm{t}_{\text {tabel }}$ \\
\hline Pemahaman & $\bar{X}$ & $\mathrm{~S}$ & $\mathrm{~S}^{2}$ & $\bar{X}$ & $\mathrm{~S}$ & $\mathrm{~S}^{2}$ & \\
\hline
\end{tabular}

$\mathrm{H}_{0}=$ tidak terdapat perbedaan kemampuan pemahaman matematis siswa antar kelas kelas eksperimen dan kelas kontrol

Nilai $-t_{\text {hitung }}<-t_{\text {tabel }}$. Sesuai dengan pengajuan hipotesis, untuk data postes kemampuan pemahaman matematis dapat disimpulkan bahwa $\mathrm{H}_{0}$ ditolak, artinya terdapat perbedaan rata-rata kemampuan pemahaman matematis siswa antara kelas kontol dan kelas eksperimen.

Tabel 10. Uji Beda rata-rata kemampuan akhir pemahaman matematis

\begin{tabular}{lcccccccc}
\hline \multirow{2}{*}{ Kemampuan } & \multicolumn{3}{c}{ Kelas Kontrol } & \multicolumn{3}{c}{ Kelas Eksperimen } & \multirow{2}{*}{$\mathrm{t}_{\text {hitung }}$} & \multirow{2}{*}{$\mathrm{t}_{\text {tabel }}$} \\
\hline Pemahaman & $\bar{X}$ & $\mathrm{~S}$ & $\mathrm{~S}^{2}$ & $\bar{X}$ & $\mathrm{~S}$ & $\mathrm{~S}^{2}$ & \\
\hline
\end{tabular}

$\mathrm{H}_{0}=$ tidak terdapat perbedaan kemampuan pemahaman matematis siswa antar kelas kelas eksperimen dan kelas kontrol

Nilai $-t_{\text {hitung }}<-t_{\text {tabel. }}$. Sesuai dengan pengajuan hipotesis, untuk data postes kemampuan pemahaman matematis dapat disimpulkan bahwa $\mathrm{H}_{0}$ ditolak, artinya terdapat perbedaan rata-rata kemampuan pemahaman matematis siswa antara kelas kontol dan kelas eksperimen.

Tabel 11. Uji beda rata-rata kemampuan akhir koneksi matematis

$\mathrm{H}_{0}=$\begin{tabular}{ccccc}
\hline $\mathrm{U}_{\text {hitung }}$ & $\begin{array}{c}\text { Rata-rata } \\
\text { Gabungan }\end{array}$ & $\begin{array}{c}\text { Standar Deviasi } \\
\text { Gabungan }\end{array}$ & $\mathrm{Z}_{\text {hitung }}$ & $\mathrm{Z}_{\text {tabel }}$ \\
\hline 2407 & 1034 & 124,85 & 11,03 & 1,96 \\
\hline
\end{tabular}

Nilai $Z_{\text {tabel }} \leq Z_{\text {hitung. }}$. Dengan demikian sesuai dengan pengajuan hipotesis,untuk data pretes kemampuan koneksi matematis dapat disimpulkan bahwa $\mathrm{H}_{0}$ ditolak atau dapat dikatakan terdapat perbedaan rata-rata kemampuan koneksi matematis siswa antara kelas kontol dan kelas eksperimen.

Berdasarkan analisis data, diperoleh kesimpulan bahwa kemampuan pemahaman dan koneksi matematis terpengaruh oleh penggunaan learning cycle. Pada kelas control, pemberian metode konvensional juga mempengaruhi kemampuan pemahaman dan koneksi 
matematis. Berikut ini dipresentasikan kemampuan pemahaman dan koneksi sebelum dan setelah pembelajaran.

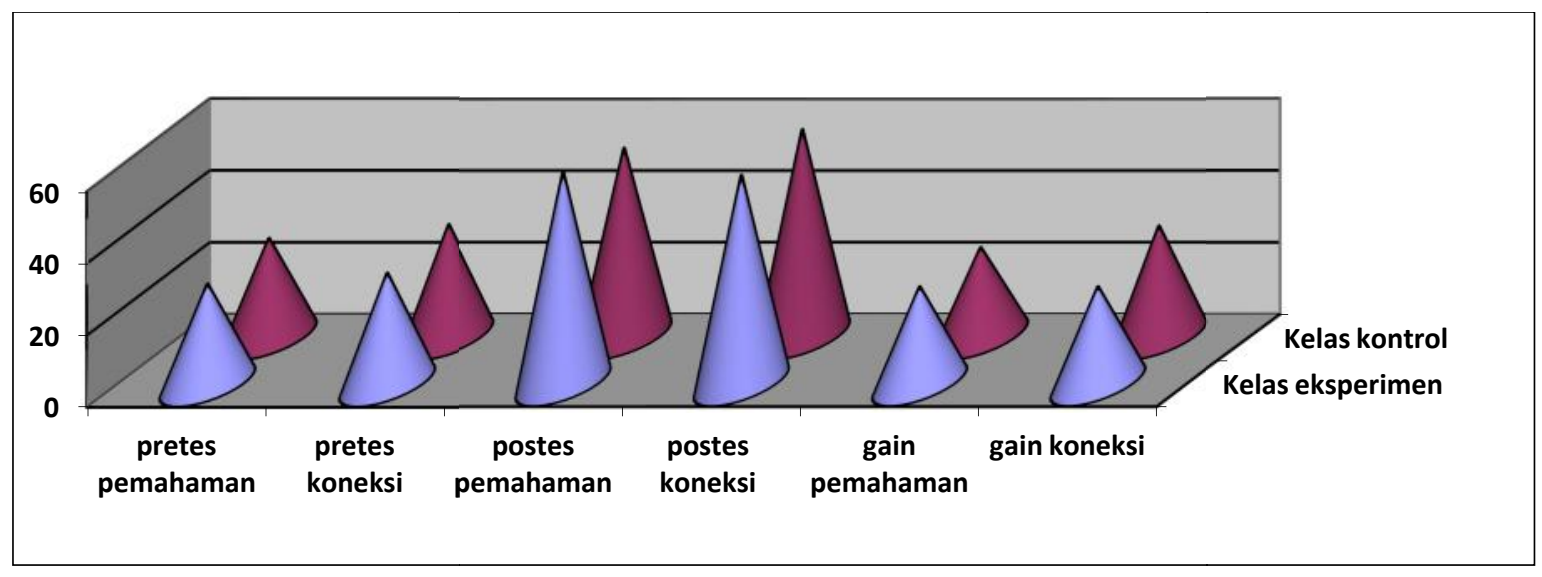

Gambar 2. Rata-rata dan gain kemampuan pemahaman dan koneksi matematis

Setelah mendapat perlakukan, kemampuan pemahaman dan koneksi matematis terlihat mengalami perkembangan. Namun demikian, tidak semua siswa baik dikelas eksperimen mapun control memperoleh hasil maksimal.

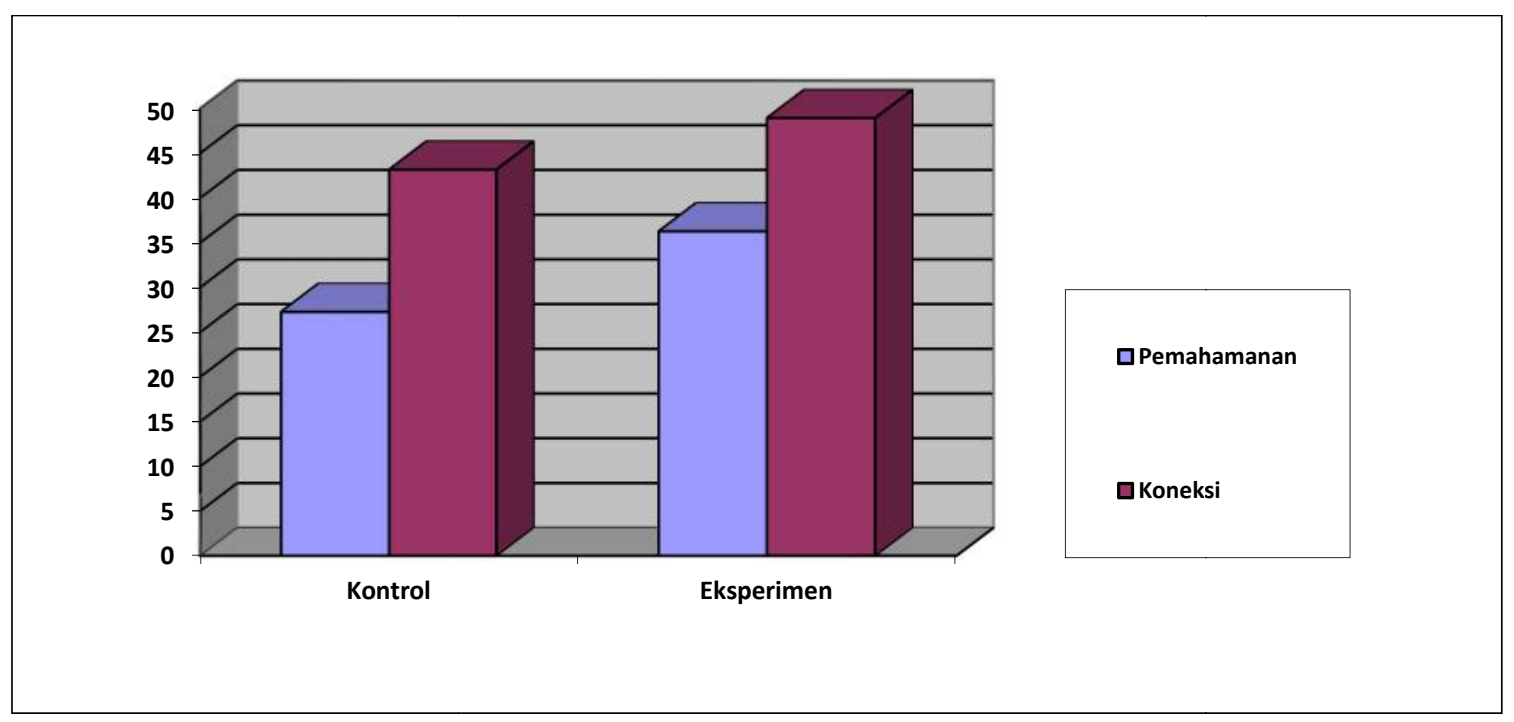

Gambar 3. Diagram Batang perolehan nilai $\geq$ KKM (dalam \%)

Hasil yang serupa diungkapkan oleh Listiyotami (2011), bahwa kemampuan koneksi matematika mengalami peningkatan setelah mendapat model pembelajaran learning cycle 5E. Hasil penelitian Suparmo (2013) mengungkapkan bawa kemampuan 
pemahaman kosep yang diberikan oleh learning cycle lebih baik daripada siswa yang mendapat pembelajaran konvensiaonal.

\section{KESIMPULAN}

Berdasarkan hasil analisis pada kemampuan pemahaman matematis menunjukkan bahwa terdapat perbedaan kemampuan pemahaman dan koneksi matematis siswa anatara kelas kontrol dan kelas eksperimen. Artinya, pemberian model pembelajaran learning cycle berpengaruh terhadap kemampuan pemahaman dan koneksi matematis siswa.

\section{REKOMENDASI}

1. Pembelajaran dengan model pembelajaran Learning Cycle menjadi salah satu model pembelajaran yang baik digunakan untuk pembelajaran matematika di jenjang SMP/MTs untuk meningkatkan kemampuan pemahaman dan koneksi matematis siswa.

2. Dalam menerapkan pembelajaran dengan model pembelajaran Learning Cycle guru sebaiknya dapat mengelola kondisi kelas seefektif mungkin karena siswa lebih sering berinteraksi dengan siswa lainnya sedangkan guru hanya mengawasi, mengarahkan dan mengevaluasi pelaksanaan pembelajaran.

3. Proses pembelajaran menggunakan model pembelajaran Learning Cycle membutuhkan waktu yang seefektif mungkin dikarenakan terdapat diskusi, pengerjaan soal, kemudian evaluasi. Kelas akan efektif jika pembagian kelompok tidak lebih dari 4 orang, hal menunjukkan bahwa model pembelajaran ini efektif jika dilaksanakan pada kelas yang jumlah siswanya tidak terlalu banyak.

4. Bagi peneliti-peneliti selanjutnya yang akan mengadakan penelitian, sebagai tinjauan ulang dari penelitian ini hendaknya mengadakan penyempurnaan sehingga lebih baik dari penelitian ini. Diharapkan mempergunakan variabel penelitian yang lebih bervariasi lagi

\section{UCAPAN TERIMAKASIH}

Terimakasih kepada keluarga besar SMP Negeri 2 Cikupa kabupaten Tangerang yang telah meyediakan tempat untuk pelaksanaan penelitian ini. 


\section{REFERENSI}

Ageng, Andoko., Turmudi, S., Tatang, Mulyana. (2014). Penerapan Model Pembelajaran Connecting-Organizing-Reflecting-Extending (CORE) untuk Meningkatkan Kemampuan Pemahaman dan Koneksi Matematis Siswa Sekolah Menengah Atas. Jurnal Penelitian dan Pembelajaran Matematika (JPPM) FKIP Untirta, 2, 89-95.

Arikunto, S. (2012). Dasar-dasar Evaluasi Pendidikan. Jakarta: Bumi Aksara.

Dimyati dan Mudjiono. (2013). Belajar dan Pembelajaran. Jakarta: Rineka Cipta.

Huda, Miftahul. (2014). Model-model Pengajaran dan Pembelajaran : Isu-isu Metodis dan Paradigmatis. Yogyakarta : Pustaka Pelajar.

Jihad, Asep \& Haris, Abdul. (2012). Evaluasi Pembelajaran. Yogyakarta : Multi Pressindo.

Ngalimun. (2014). Strategi dan Model Pembelajaran. Yogyakarta: Aswaja Pressindo

Rafianti I., Kartasasmita, B., Juandi D., (2013) Penerapan Model Pembelajaran Matematika Berbasis Multiple Intelegences untuk Meningkatkan kemampuan Pemahaman Konsep, Penalaran Matematis dan self-Confidence Siswa MTs. JPPM Vol. 6 No. 2.

Sagala, S. (2013). Konsep dan Makna Pembelajaran untuk Membantu Memecahkan Problematika Belajar dan Mengajar. Bandung: Alfabeta.

Sumarmo, U. (2013). Berfikir dan Disposisi Matematik serta Pembelajarannya. Bandung : Jurusan Pendidikan Mtematika Fakultas Pendidikan Matematika dan Ilmu Pengetahuan Alam Universitas Pendidikan Indonesia.

Sundayana, R. (2014). Statistika Penelitian Pendidikan. Bandung: Alfabeta

Suparno. (2013). Pengaruh pembelajaran Matematika Menggunakan Model Learning Cycle 7E terhadap Pemahaman Konsep dan Berfikir Kritis Siswa MA Wahid Hasyim Kelas X Yogyakarta. Program Sarjana Pendidikan Matematika. Yogyakarta: Fakultas Sains dan Teknologi. Universitas Islam Negeri Sunan Kalijaga.

Widaningsih N, Yenni. (2016). Perbandingan Kemampuan Pemahaman Matematis Siswa Antara Yang Mendapat Model Pembelajaran Course Review Horay Dan Numbered Head Together. JPPM Vol. 9 No 1.

Yenni. (2012). Peningkatan Kemampuan Pemahaman dan Penalaran Matematis Santri Putra dan Santri Putri melalui Metode Pembelajaran Kooperatif tipe TGT pada MTS Berbasis Pesantren. Bandung: Universitas Pendidikan Indonesia. 
